\title{
Predictors of Health Insurance, Life Insurance, and Retirement Savings Among NYC's Immigrant Taxi and For-Hire Vehicle Drivers
}

\author{
Francesca Gany ${ }^{1,2}$ (D) Sheena Mirpuri ${ }^{1} \cdot$ Soo Young Kim ${ }^{1} \cdot$ Bharat Narang $^{1} \cdot$ Julia Ramirez $^{1} \cdot$ Nicole Roberts-Eversley $^{1}$. \\ Alex Ocampo ${ }^{1} \cdot$ Abraham Aragones $^{1,2} \cdot$ Jennifer Leng ${ }^{1,2}$
}

Published online: 17 August 2020

(c) Springer Science+Business Media, LLC, part of Springer Nature 2020

\begin{abstract}
Taxi and for-hire vehicle (FHV) drivers are a predominantly immigrant population facing a range of occupational stressors, including lack of workplace benefits and increasing financial strain from tumultuous industry changes and now COVID-19's devastating impact. Bilingual research staff surveyed 422 New York City taxi/FHV drivers using a stratified sampling approach in driver-frequented locations to examine drivers' health and financial planning behaviors for the first time. Drivers lacked health insurance at double the NYC rate (20\% vs. $10 \%)$. Life insurance and retirement savings rates were lower than U.S. averages ( $20 \%$ vs. $60 \%, 25 \%$ vs. $58 \%$, respectively). Vehicle ownership was a significant predictor of health insurance, life insurance, and retirement savings. Compared to South Asian drivers, Sub-Saharan African drivers were significantly less likely to have health insurance and North African, and Middle Eastern drivers were significantly less likely to have retirement savings. Although most drivers indicated the importance of insurance and benefits, $<50 \%$ understood how to use them. Drivers felt primary care coverage to be most important followed by other health-related coverage, retirement benefits, and life insurance. Results reveal compelling addressable gaps in insurance and benefits coverage and the need to implement accessible financial literacy with navigation and advising services and programs.
\end{abstract}

Keywords Social determinants of health $\cdot$ Health disparities $\cdot$ Health insurance $\cdot$ Taxi drivers $\cdot$ Immigrant

\section{Introduction}

Taxi and for-hire vehicle (FHV) drivers comprise an ethnically diverse workforce facing mounting financial pressures $[1,2]$ and work-related health risks [1,3-5]. Taxi drivers are part of a fast-growing occupational group in the US, which more than doubled from 305,000 in 2016 to 703,000 in 2019 with the increasing popularity of ride-sharing apps, such as Uber and Lyft [6, 7]. There are approximately 187,467 licensed taxi/FHV drivers in New York City (NYC), mostly

Francesca Gany and Sheena Mirpuri have contributed equally to this work.

Francesca Gany

ganyf@mskcc.org

1 Immigrant Health and Cancer Disparities Service, Department of Psychiatry and Behavioral Sciences, Memorial Sloan Kettering Cancer Center, 485 Lexington Avenue, 2nd FL, New York, NY 100065, USA

2 Department of Public Health, Weill Cornell Medical College, New York, NY, USA male (95\%) and immigrant (91\%) [8]. They drive medallion yellow taxis (street-hail taxis allowed to pick up passengers throughout NYC), green taxis (street hail-taxis allowed to pick up passengers outside designated areas of Manhattan), traditional FHVs (typically pre-arranged black cars and limousines), and app-based FHVs.

The documented financial pressures NYC FHV drivers face include a recent significant drop in the value of medallions and increased competition [8-10]. Similarly, in San Francisco, the taxi industry is suffering from staggering declines and drivers experience enormous financial pressures [11]. As independent contractors, they are not entitled to work-sponsored insurance, including health insurance and life insurance, paid sick leave, or retirement savings programs [12]. Studies suggest that ongoing financial strain can have negative consequences for mental and physical health $[13,14]$. Reports indicate that mental health is a serious and mounting concern among drivers; in 2018, eight NYC taxi drivers committed suicide, which may have been linked to the plummeting medallion value [15]. Prior research has indicated that taxi and FHV drivers are subject 
to a confluence of occupational factors that can negatively impact their interrelated financial, mental, and physical health. Drivers have reported that stress, discrimination, long hours, and low pay contribute to their poor health outcomes $[1,4,16]$. In metropolitan cities across the world, researchers have documented a range of health and wellness issues in taxi drivers, including fatigue [17], compromised immune function [18], chronic pain [19], diabetes [17], and increased cardiovascular disease and cancer risk [3, 20-22].

The advent of COVID-19 has added to drivers' financial strain and occupational health risk, and it has exposed the pernicious nature of their lack of workplace financial benefits, including sick pay and health insurance, as it has for many of the nation's working poor [23-25]. As most drivers in NYC are male and of minority backgrounds, and with their high rates of overweight, obesity, and other comorbidities, they are among the most vulnerable to COVID-19 infection and death [26].

Despite their financial and health challenges, researchers have not yet examined drivers' engagement in processes that could be salutary for their long-term physical and financial health, such as planning behaviors that include health insurance, life insurance, and savings or their general financial literacy. Explanations for the pursuit of insurance and savings have primarily addressed the broad notion that individuals struggle with complex information (bounded rationality) $[27,28]$, potentially making poorer judgments around the probability of certain events, which may be especially true with understanding insurance enrolments and plans [29]. This may be compounded by loss aversion, whereby spending money in the present (on insurance premiums, savings accounts, etc.) to manage the effects of future risks (illness, old age, death) may not be enticing, particularly when other more pressing financial priorities exist.

There may be socioeconomic and structural barriers to obtaining insurance and benefits, including ethnic/ racial discrimination, occupational status, language barriers, immigration status, documentation, income, and lack of purchasing awareness and power. Most drivers are male first-generation immigrants who potentially have limited employment opportunities and social safety nets while having dependent families, which amplifies the importance of their health and finances. Investigation of their insurance behaviors is important because it could deepen understanding of health and financial behavior predictors among marginalized and mobile populations that typically remain under the radar, providing policymakers, medical professionals, and community-based organizations with important data to guide integrated interventions that will more effectively address overall health in these populations.

As an initial step to understanding the health and financial planning behaviors among taxi/FHV drivers and to expanding uptake of insurance and savings behavior, this study examined the current status of three main financial planning outcomes among NYC drivers: health insurance, life insurance, and retirement savings. We also examined predictors of these outcomes, including drivers' demographic (age, region of birth), workplace (vehicle type, ownership, work shift), and financial (income, financial strain) profiles. We further investigated whether drivers had ever consulted with a financial counselor, the types of financial resources and benefits that drivers have and want, and their understanding and ranking of these benefits' importance. This information can inform interventions to promote uptake of financial planning among the working poor and lessen the impact of health calamities, such as COVID-19, on their and their families' overall financial health and mental and physical wellbeing.

\section{Materials and Methods}

\section{Sample}

We used stratified sampling to recruit taxi and FHV drivers in the NYC metropolitan area for participation in this study. Inclusion criteria included being aged $>18$ years and fulltime driving ( $\geq 35 \mathrm{~h} /$ week). Drivers were stratified by region of origin, age group (19-40 years, $41-55$ years, $>55$ years), and type of driving arrangement (medallion yellow taxi, green taxi, traditional FHV, and app-based FHV) in proportion to the NYC taxi and FHV driving population, based on Taxi and Limousine Commission data [30]. It was estimated that a sample size of approximately 400 would allow us to detect differences of $10 \%$ for binary variables between each type of driving arrangement, with $80 \%$ power.

\section{Survey Instrument}

\section{Independent Variables}

Demographics Variables included gender, age, English proficiency, and birthplace. Drivers' countries of birth were collected and collapsed into regions: East Asia/Tibet/ Southeast Asia (China, South Korea, Taiwan, Tibet, and Cambodia); Latin America (Brazil, Colombia, Dominican Republic, Ecuador); North Africa and Middle East (Afghanistan, Algeria, Azerbaijan, Egypt, Israel, Morocco, Turkey, Uzbekistan, Yemen); South Asia (Bangladesh, India, Nepal, Pakistan); and Sub-Saharan Africa (Benin, Burkina Faso, Chad, Eritrea, Ethiopia, Ghana, Guinea, Guyana, Ivory Coast, Mali, Mauritania, Nigeria, Senegal, Sierra Leone, Sudan).

Driving Arrangement Information on driving arrangement and work shift (day/night/varied) was collected. Drivers were also asked about vehicle ownership (own/lease/bor- 
row/rent); these categories were recoded into a binary variable: $0=$ Don't own (lease/borrow/rent), $1=$ Own.

Financial Profile Drivers were asked whether they had ever met with a financial advisor and queried on their average weekly income after vehicle-related expenses. To ascertain financial strain, drivers were asked whether their total household income met their and their families' basic needs. Response options included "No, it is often difficult to cover all household expenses;" "Yes, it is just enough to cover all expenses;" or "Yes, it is enough to cover expenses with some left over." If drivers indicated the last option, they were asked to specify how much money they saved per week.

\section{Primary outcomes}

Health Insurance Coverage Coverage was determined based on a binary Yes/No response to one item: "Do you have any kind of health insurance coverage, including private health insurance, government plans such as Medicaid or Medicare, VA (or other coverage for veterans), etc.?" Drivers who indicated having health insurance were asked to specify whether they had coverage for primary care, specialist care, mental health, prescriptions, vision care, and dental health.

Life Insurance Coverage Drivers were asked whether they currently had life insurance. Response options were "Yes" and "No."

Retirement Savings Drivers were asked whether they saved for retirement, apart from social security contributions. Response options were "Yes" and "No."

\section{Secondary Outcomes}

Understanding and Importance of Insurance and Benefits Drivers were presented with a list of insurance coverage and benefits, including primary, specialist, mental health, and vision care; dental health; prescription coverage; retirement; life insurance; personal disability insurance; paid sick time; supplemental workers' compensation insurance; unemployment insurance; family leave; paid vacation; and wellness program benefits. Each benefit was defined for participants prior to questioning. Drivers were asked how well they understood each one. Responses were based on a 4-point Likert scale: Not at all, Not well, Well, and Very well. We also queried drivers on the importance of each of these benefits to them. Responses were based on a 5-point Likert scale: Not important, Slightly important, Moderately important, Important, and Very important.

Ranking and Magnitude of Benefits Importance Drivers were asked to consider that they had $\$ 100$ to spend towards the various benefits and then asked how they would allocate that money in $\$ 5$ increments, based on level of importance to them.

\section{Translations}

To account for the most common languages spoken by NYC's taxi and FHV drivers, the survey tool was developed in English and then forward and back translated into Bengali, Spanish, French, Urdu, Chinese, and Hindi.

\section{Data Collection Procedures}

This study was determined to be exempt research by the Institutional Review Board at Memorial Sloan Kettering Cancer Center. An interviewer-administered survey was conducted with NYC taxi/FHV drivers approached from December 5, 2016 through January 23, 2017 at airport taxi holding lots (John F. Kennedy and LaGuardia airports), community- and faith-based organizations, taxi garages, and workplaces, and street-side. Drivers were approached before, during, and after work. Bilingual research staff approached drivers to complete a screening survey to determine eligibility. Eligible drivers were given a brief survey description. If drivers agreed to participate, they were led to a semi-private area for oral consent and survey administration. Research staff read out survey items and recorded participants' responses electronically on study tablets (51\%). When electronic data entry was not feasible (e.g., WIFI hotspot unavailable or participant chose to take the survey in a non-English language), data were recorded on paper (49\%) and later entered into the electronic system. Survey duration was approximately $25-40 \mathrm{~min}$. Participants received a $\$ 50$ gift card for their time.

\section{Data Analyses}

We chose to examine predictors of health insurance, life insurance, and retirement savings, as these were the most commonly reported types of insurance and savings; other nonhealth related benefits and insurance were reported by less than $5 \%$ of the sample. Sociodemographic, driving arrangement, and financial profile variables significantly associated with each outcome variable (health insurance, life insurance, and retirement savings) were identified using a binary logistic regression. The variables were then included in the multivariate logistic regression model based on a statistically significant association per outcome variable on bivariate analysis. Each model was adjusted for covariates, including age, monthly gross income and birth region-South Asia was selected as the reference category, as it had the largest number of participants due to class imbalance-and checked for multicollinearity. Analyses examining demographic differences in the 
understanding and importance of each benefit included Chi square tests, Fisher's exact tests, and $t$ tests, as appropriate. All statistical associations were evaluated at a significance level of .05 (2-sided type I error rate). Statistical analyses were conducted using R software (R Foundation for Statistical Computing, Vienna, Austria).

\section{Results}

\section{Demographics}

A total of 422 taxi and FHV drivers were included (Table 1). Most participants were male (97\%), with a mean age of 45 years $(\mathrm{SD}=12)$. Among drivers born outside of the U.S. (97\%), the most common region of birth was South Asia (36\%). Drivers reported living in the U.S. for an average of 19.9 years $(\mathrm{SD}=11)$ and an average of 13 years of education $(\mathrm{SD}=4)$. Twenty-eight percent of drivers indicated speaking English very well. Most participants were married (73\%). Of those drivers that were married or partnered $(75 \%)$, $85 \%$ lived with their spouse/partner, and $43 \%$ reported having children under the age of 18 in the household. Drivers reported the following driving arrangements: medallion yellow taxi (29\%), traditional FHV (27\%), app-based FHV (26\%), and green taxi (18\%). Fifty-two percent of drivers owned their vehicles, and most drivers worked day shifts (57\%).

\section{Financial Profile}

The median reported household gross income was $\$ 3000$ / month, with 55\% of drivers making between $\$ 2000$ and $\$ 3999 /$ month (Table 1). Fifty-nine drivers chose to report their monthly income using ranges as opposed to reporting approximate income. Of these drivers, most reported earning \$2401-\$3300 (23\%) and \$3301-\$5000 (20\%). On average, drivers reported earning $\$ 696(\mathrm{SD}=\$ 290$, range $=\$ 0-\$ 2000$ ) weekly after paying for vehicle-related expenses. Fifty-five percent indicated that it was often difficult to cover all household expenses, $33 \%$ said that their income was just enough to cover all expenses, and $12 \%$ indicated that they were able to cover all expenses with some left over. Of these 51 drivers, 44 reported an average of \$266 ( $\mathrm{SD}=\$ 197$, range: $\$ 24-900)$ left over weekly, and 7 drivers did not report the amount. Only $10 \%$ of drivers indicated that they had ever visited a financial advisor.

\section{Associations Between Health Insurance, Life Insurance, and Retirement Savings}

As shown in Table 2, we found a significant association between (a) having life insurance and health insurance $\left(\chi^{2}=5.151, p<.001\right): 18 \%$ of drivers had both life and
Table 1 Demographic profile of taxi and FHV drivers in NYC $(\mathrm{N}=422)$

\begin{tabular}{|c|c|}
\hline Characteristics & No. $(\%) / \mu(\mathrm{SD})^{\mathrm{a}}$ \\
\hline \multicolumn{2}{|l|}{ Gender } \\
\hline Male & $411(97)$ \\
\hline Female & $11(3)$ \\
\hline $\operatorname{Age}^{\mathrm{a}}$ & $45(12.4)$ \\
\hline \multicolumn{2}{|l|}{ Monthly gross income ${ }^{\mathrm{b}}$} \\
\hline$\leq \$ 1999$ & $53(15)$ \\
\hline \$2000-3999 & $192(55)$ \\
\hline$\$ 4000-5999$ & $72(21)$ \\
\hline$\geq \$ 6000$ & $30(9)$ \\
\hline Weekly income after paying for vehicle expenses ${ }^{c}$ & $723.73(634.2)$ \\
\hline \multicolumn{2}{|l|}{ Financial strain $^{\mathrm{d}}$} \\
\hline Difficult to cover expenses & $223(55)$ \\
\hline Just enough to cover expenses & $135(33)$ \\
\hline Can cover expenses with leftover & $51(12)$ \\
\hline Has visited a financial counselor ${ }^{\mathrm{d}}$ & $41(10)$ \\
\hline Wants financial counselling services & $175(41)$ \\
\hline \multicolumn{2}{|l|}{ Marital status ${ }^{\mathrm{d}}$} \\
\hline Married & $307(73)$ \\
\hline Not married & $114(27)$ \\
\hline Years of education ${ }^{\mathrm{d}}$ & $13.4(4.0)$ \\
\hline Years in the U.S. ${ }^{d}$ & $19.9(11.0)$ \\
\hline \multicolumn{2}{|l|}{ Birth Region ${ }^{\mathrm{d}}$} \\
\hline Sub-Saharan Africa & $81(19)$ \\
\hline East Asia/Tibet/Southeast Asia & $19(5)$ \\
\hline Latin America & $85(20)$ \\
\hline North Africa/Middle East/Central Asia & $44(10)$ \\
\hline South Asia & $150(36)$ \\
\hline Other & $42(10)$ \\
\hline \multicolumn{2}{|l|}{ English proficiency ${ }^{\mathrm{d}}$} \\
\hline Very well & $116(28)$ \\
\hline Well/not well/not at all & $303(72)$ \\
\hline \multicolumn{2}{|l|}{ Work shift ${ }^{\mathrm{d}}$} \\
\hline Day & $242(57)$ \\
\hline Night & $69(16)$ \\
\hline Varies & $110(26)$ \\
\hline \multicolumn{2}{|l|}{ Vehicle type } \\
\hline App-based FHV & $108(26)$ \\
\hline Green cab & $76(18)$ \\
\hline Medallion yellow cab & $124(29)$ \\
\hline Traditional FHV & $114(27)$ \\
\hline \multicolumn{2}{|l|}{ Vehicle ownership ${ }^{\mathrm{d}}$} \\
\hline Own & $214(52)$ \\
\hline \multicolumn{2}{|l|}{ Health insurance $^{\mathrm{d}}$} \\
\hline Yes & $336(80)$ \\
\hline \multicolumn{2}{|l|}{ Life insurance ${ }^{\mathrm{d}}$} \\
\hline Yes & $83(20)$ \\
\hline \multicolumn{2}{|l|}{ Retirement savings $^{\mathrm{d}}$} \\
\hline Yes & $102(25)$ \\
\hline \multicolumn{2}{|c|}{${ }^{\mathrm{a}} \mu$ (SD): Mean and standard deviation for continuous variables } \\
\hline \multicolumn{2}{|l|}{${ }^{b} 18 \%$ data missing $(n=75)$} \\
\hline \multicolumn{2}{|l|}{${ }^{\mathrm{c}} 14 \%$ data missing $(\mathrm{n}=57)$} \\
\hline${ }^{d} \leq 4 \%$ data missing $(n=1-16)$ & \\
\hline
\end{tabular}


health insurance and $2 \%$ had life insurance only ( $20 \%$ of all drivers had life insurance); and (b) having retirement savings and life insurance $\left(\chi^{2}=24.014, p<.001\right)$, with $9 \%$ of drivers having both life insurance and retirement savings, $16 \%$ having retirement savings only, and $11 \%$ having life insurance only. However, there was no significant association between having health insurance and retirement savings.

\section{Health Insurance}

Approximately $80 \%$ of drivers reported having health insurance (Table 1). Most described having medical (80\%), vision $(64 \%)$, and dental health $(66 \%)$ care benefits, and almost half had mental health benefits (48\%) (Table 3).

Table 2 Binary logistic regression predicting probability of health insurance coverage, life insurance coverage, and retirement savings

\begin{tabular}{|c|c|c|c|c|c|c|}
\hline & \multicolumn{2}{|c|}{ Health insurance $(n=421)$} & \multicolumn{2}{|c|}{ Life insurance $(\mathrm{n}=417)$} & \multicolumn{2}{|c|}{ Retirement savings $(n=416)$} \\
\hline & $\begin{array}{l}\text { Bivariate OR } \\
(95 \% \mathrm{CI})\end{array}$ & $\begin{array}{l}\text { Multivariate OR } \\
(95 \% \mathrm{CI})\end{array}$ & $\begin{array}{l}\text { Bivariate OR } \\
(95 \% \mathrm{CI})\end{array}$ & $\begin{array}{l}\text { Multivariate OR } \\
(95 \% \text { CI })\end{array}$ & $\begin{array}{l}\text { Bivariate OR } \\
(95 \% \mathrm{CI})\end{array}$ & $\begin{array}{l}\text { Multivariate OR } \\
(95 \% \mathrm{CI})\end{array}$ \\
\hline Age & $1.18(0.97,1.43)$ & $1.14(0.89,1.47)$ & $1.23(1.01,1.50)^{*}$ & $0.84(0.55,1.28)$ & $0.94(0.78,1.12)$ & $0.83(0.64,1.07)$ \\
\hline \multicolumn{7}{|c|}{ Monthly household income (Ref: $\geq \$ 6000$ ) } \\
\hline$\leq \$ 1999$ & $0.66(0.19,2.33)$ & $0.86(0.23,3.28)$ & $0.36(0.13,1.02)$ & $1.05(0.27,3.99)$ & $0.43(0.16,1.17)$ & $1.10(0.33,3.66)$ \\
\hline$\$ 2000-3999$ & $0.64(0.21,1.96)$ & $0.68(0.21,2.19)$ & $0.41(0.18,0.95)^{*}$ & $0.55(0.20,1.56)$ & $0.54(0.24,1.22)$ & $0.68(0.26,1.77)$ \\
\hline$\$ 4000-5999$ & $0.46(0.14,1.50)$ & $0.43(0.12,1.49)$ & $0.39(0.15,1.01)$ & $0.38(0.11,1.28)$ & $0.52(0.21,1.33)$ & $0.62(0.21,1.84)$ \\
\hline \multicolumn{7}{|c|}{ Financial strain (Ref: difficult to cover expenses) } \\
\hline $\begin{array}{l}\text { Just enough to } \\
\text { cover expenses }\end{array}$ & $0.87(0.51,1.48)$ & & $1.21(0.69,2.12)$ & $0.87(0.41,1.83)$ & $1.59(0.95,2.66)$ & $1.26(0.67,2.39)$ \\
\hline $\begin{array}{l}\text { Enough to cover } \\
\text { expenses with } \\
\text { left over }\end{array}$ & $0.74(0.35,1.53)$ & & $\begin{array}{l}3.07(1.57 \\
6.00)^{* *}\end{array}$ & $3.55(1.41,8.97)^{* *}$ & $\begin{array}{r}3.67(1.90 \\
7.09)^{* * *}\end{array}$ & $3.16(1.39,7.20)^{* *}$ \\
\hline Married & $\begin{array}{r}0.41(0.25 \\
0.68)^{* * *}\end{array}$ & $0.63(0.33,1.19)$ & $0.89(0.51,1.54)$ & & $1.15(0.70,1.89)$ & \\
\hline $\begin{array}{l}\text { Years of educa- } \\
\text { tion }\end{array}$ & $0.91(0.50,1.65)$ & & $\begin{array}{l}2.90(1.44 \\
5.85)^{* *}\end{array}$ & $3.98(1.63,9.71)^{* *}$ & $\begin{array}{c}2.65(1.39 \\
5.05)^{* *}\end{array}$ & $\begin{array}{l}4.84(1.99 \\
11.79)^{* * *}\end{array}$ \\
\hline Years in U.S. & $1.19(0.94,1.49)$ & & $\begin{array}{r}1.50(1.20 \\
1.88)^{* * * *}\end{array}$ & $\begin{array}{r}2.20(1.39 \\
3.49)^{* * * *}\end{array}$ & $0.98(0.79,1.20)$ & \\
\hline \multicolumn{7}{|c|}{ Birth Region (Ref: South Asia) } \\
\hline $\begin{array}{l}\text { Sub-Saharan } \\
\text { Africa }\end{array}$ & $\begin{array}{r}0.27(0.14 \\
0.53)^{* * *}\end{array}$ & $0.30(0.14,0.64)^{* *}$ & $0.55(0.26,1.16)$ & $0.63(0.24,1.66)$ & $0.93(0.50,1.72)$ & $1.01(0.45,2.25)$ \\
\hline $\begin{array}{l}\text { East Asia/Tibet/ } \\
\text { Southeast Asia }\end{array}$ & $0.77(0.21,2.91)$ & $0.54(0.14,2.17)$ & $1.23(0.41,3.68)$ & $0.84(0.18,3.99)$ & $1.32(0.47,3.77)$ & $0.79(0.23,2.74)$ \\
\hline Latin America & $0.58(0.28,1.19)$ & $0.61(0.24 .1 .53)$ & $0.62(0.31,1.26)$ & $0.57(0.19,1.69)$ & $0.77(0.41,1.45)$ & $1.12(0.44,2.82)$ \\
\hline $\begin{array}{l}\text { North Africa/ } \\
\text { Middle East/ } \\
\text { Central Asia }\end{array}$ & $0.49(0.21,1.16)$ & $0.63(0.23,1.72)$ & $0.67(0.26,1.65)$ & $0.51(0.16,1.65)$ & $0.27(0.09,0.79)^{*}$ & $0.17(0.44,2.82)^{*}$ \\
\hline Other & $0.70(0.27,1.81)$ & $0.71(0.25,2.00)$ & $1.73(0.82,3.65)$ & $0.52(0.17,1.62)$ & $0.94(0.43,2.05)$ & $0.58(0.22,1.55)$ \\
\hline $\begin{array}{l}\text { English profi- } \\
\text { ciency: very well }\end{array}$ & $1.29(0.74,2.25)$ & & $1.94(1.17,3.22)^{*}$ & $1.60(0.77,3.33)$ & $1.13(0.69,1.85)$ & \\
\hline \multicolumn{7}{|l|}{ Work shift (Ref: day) } \\
\hline Night & $0.65(0.34,1.23)$ & & $0.88(0.44,1.78)$ & & $0.95(0.51,1.77)$ & \\
\hline Varies & $0.68(0.39,1.18)$ & & $1.20(0.69,2.09)$ & & $0.73(0.42,1.27)$ & \\
\hline \multicolumn{7}{|c|}{ Vehicle type (Ref: Green Cab) } \\
\hline App based FHV & $0.59(0.27,1.30)$ & & $2.88(1.17,7.09)^{*}$ & $6.57(1.37,31.55)^{*}$ & $2.76(1.17,6.50)^{*}$ & $2.29(0.71,7.40)$ \\
\hline Medallion yellow & $0.57(0.27,1.23)$ & & $2.70(1.11,6.57)^{*}$ & $6.79(1.35,34.15)^{*}$ & $\begin{array}{l}3.66(1.60 \\
8.37)^{* *}\end{array}$ & $5.22(1.58,17.26)^{* *}$ \\
\hline Traditional FHV & $0.71(0.32,1.56)$ & & $2.76(1.13,6.76)^{*}$ & $5.19(1.14,23.67)^{*}$ & $\begin{array}{l}3.29(1.42 \\
7.64)^{* *}\end{array}$ & $3.28(1.06,10.11)^{*}$ \\
\hline Vehicle owner & $\begin{array}{l}2.14(1.31 \\
3.51)^{* *}\end{array}$ & $1.90(1.02,3.54)^{*}$ & $\begin{array}{c}2.04(1.23 \\
3.38)^{* *}\end{array}$ & $2.94(1.31,6.63)^{* *}$ & $1.66(1.05,2.62)^{*}$ & $2.66(1.31,5.41)^{* *}$ \\
\hline
\end{tabular}

$O R$ odds ratio, $C I$ confidence interval

$*<0.05 ; * *<0.01 ; * * *<0.001$ 
Seventy-nine percent of drivers with health insurance reported prescription coverage (not shown).

Based on bivariate analyses, marital status, region of birth, and vehicle ownership were significantly associated with health insurance status (Table 2). Of drivers with insurance, $12 \%$ obtained insurance through their spouse/partner. A multivariate logistic regression including these variables and controlling for age and income indicated that only region of birth and vehicle ownership significantly predicted health insurance coverage. Sub-Saharan African drivers were significantly less likely than South Asian drivers to have health insurance $(0.30$ OR; $95 \%$ CI $0.14,0.64)$ and vehicle owners were significantly more likely to have health insurance (1.90 OR; 95\% CI 1.02, 3.54).

\section{Life Insurance}

Only 20\% of drivers reported having life insurance (Table 3). Bivariate analyses indicated that age, income, financial strain, years of education, years in the U.S., English proficiency, vehicle type, and vehicle ownership were all significantly associated with whether a driver had life insurance (Table 2). A multivariate regression model including these variables, controlling for age, income, and region of birth, found that financial strain, years of education, years in the U.S., vehicle type, and vehicle ownership remained significant predictors of life insurance coverage. Drivers who reported that they were able to cover their expenses with some left over were more likely to have life insurance (3.55 OR; 95\% CI 1.41, 8.97) than drivers who reported that it was difficult to cover their household expenses. Drivers with more years of education (3.98 OR; 95\% CI 1.63, 9.71) and who had lived in the U.S. longer (2.20 OR; 95\% CI 1.39, 3.49) were more likely to have life insurance coverage. In comparison to green taxi drivers, app-based FHV drivers (6.57 OR; 95\% CI 1.37, 31.55), medallion yellow taxi drivers (6.79 OR; 95\% CI 1.35, 34.15), and traditional FHV drivers $(5.19$ OR; 95\% CI 1.14, 23.67) were all significantly more likely to have life insurance coverage. Finally, vehicle owners were also more likely than non-owners to have life insurance (2.94 OR; 95\% CI 1.31, 6.63).

\section{Retirement Savings}

Only $25 \%$ of drivers reported saving for their retirement (Table 1). Bivariate analyses indicated that financial strain, marital status, region of birth, vehicle type, and vehicle ownership were significantly associated with having retirement savings (Table 2). Controlling for age and income, these variables were entered into a multivariate logistic regression model. All remained significant. Drivers who reported that they were able to cover expenses with some left over were more likely to have retirement savings (3.16 OR; 95\% CI $1.39,7.20)$ than drivers who noted that expenses were difficult to cover. Drivers who were married were over four times more likely to have retirement savings (4.84 OR; 95\% CI $1.99,11.79)$ than unmarried drivers. In comparison to South Asian drivers, North African and Middle Eastern drivers were significantly less likely to have retirement savings (0.17 OR; 95\% CI 0.44, 2.82). With regard to vehicle type,
Table 3 Descriptive summary of insurance benefits. Drivers with health insurance reported how well they understood how to get care with the categories of health insurance they reported possessing (lines a-f). All drivers were asked how well they understood how other financial benefits/resources work (lines g-o)

\begin{tabular}{|c|c|c|c|c|}
\hline Benefit & $\begin{array}{l}\text { Have ben- } \\
\text { efit }(\%)\end{array}$ & $\begin{array}{l}\text { Rated understanding } \\
\text { very well }(\%)\end{array}$ & $\begin{array}{l}\text { Rated very } \\
\text { important }(\%)\end{array}$ & $\begin{array}{l}\text { Mean US dol- } \\
\text { lar allocation }\end{array}$ \\
\hline a. Primary health care ${ }^{a}$ & 80 & 33 & 76 & 20 \\
\hline b. Specialist health care ${ }^{a}$ & - & 24 & 76 & 9 \\
\hline c. Vision health care & 64 & 31 & 68 & 8 \\
\hline d. Dental health care & 66 & 39 & 73 & 10 \\
\hline e. Mental health care & 48 & 32 & 47 & 3 \\
\hline f. Prescription coverage & - & - & - & 8 \\
\hline g. Life insurance & 20 & 29 & 45 & 8 \\
\hline h. Personal disability insurance & 6 & 20 & 51 & 4 \\
\hline i. Paid sick time & 2 & 25 & 60 & 4 \\
\hline $\begin{array}{l}\text { j. Supplemental worker's compen- } \\
\text { sation insurance }\end{array}$ & - & 17 & 51 & 3 \\
\hline k Unemployment insurance & 4 & 27 & 56 & 4 \\
\hline 1. Family leave & - & 17 & 53 & 3 \\
\hline m. Paid vacation & 2 & 37 & 58 & 3 \\
\hline n. Wellness programs & 4 & 17 & 42 & 2 \\
\hline o. Retirement benefits & 25 & 25 & 71 & 9 \\
\hline
\end{tabular}

${ }^{\text {a } R e s p o n d e n t s ~ w e r e ~ a s k e d ~ t o ~ r a t e ~ P r i m a r y ~ H e a l t h ~ C a r e ~ a n d ~ S p e c i a l i s t ~ H e a l t h ~ C a r e ~ t o g e t h e r: ~ " H o w ~ i m p o r t a n t ~}$ is having health insurance that covers primary care and specialist doctors, hospitalization and medical testing to you? 
medallion yellow taxi drivers (5.22 OR; 95\% CI 1.58, 17.26) and traditional FHV drivers (3.28 OR; 95\% CI 1.06, 10.11) were significantly more likely than green taxi drivers to have retirement savings. Bivariate associations indicated that appbased drivers were also more likely than green taxi drivers to have retirement savings; however, this finding was not significant in the multivariate regression model. Finally, the odds of having retirement savings were 2.66 times higher for vehicle owners than for non-owners $(2.66 \mathrm{OR}$; $95 \% \mathrm{CI}$ $1.31,5.41)$.

\section{Understanding of Health and Financial Resources}

Drivers with health insurance were asked how well they understood getting care with the health insurance categories that they reported (Table 3, lines a-f). All drivers were asked how well they understood how other financial benefits/resources work (Table 3, lines g-o). Overall, $<50 \%$ of drivers reported understanding how to use these health and financial resources very well. Just $24-39 \%$ of drivers reported understanding various health-related services very well, with dental health services being the best understood (39\%) and specialist health care the least understood (24\%). Among, non-health related resources, the largest percentage of drivers reported understanding how to use paid vacation very well (37\%), versus $17 \%$ of drivers understanding how to use family leave, supplemental worker's compensation insurance, and wellness programs.

We also examined demographic differences in the understanding of our three primary foci: health insurance coverage, life insurance coverage, and retirement savings (Table 4). Drivers who indicated understanding health insurance and retirement savings very well were, on average, older. Drivers who indicated understanding all three foci very well reported having lived in the U.S. for longer and speaking English very well.

\section{Importance of Health and Financial Resources}

Among health-related benefits, the overwhelming majority of drivers indicated that these were very important (Table 3): primary and specialist care (76\%), dental care (73\%), vision care (68\%), and, to a lesser extent, mental health care (47\%). Among non-health related benefits, they indicated retirement savings (71\%), paid sick time (60\%), paid vacation $(58 \%)$, unemployment insurance (56\%), family leave (53\%), disability insurance (51\%), supplemental workers' compensation $(51 \%)$, life insurance $(45 \%)$, and wellness program benefits $(42 \%)$.

When drivers were asked to allocate a hypothetical $\$ 100$ towards various benefits, on average, they made the following choices (Table 3): \$20 to health insurance to cover primary care, $\$ 10$ on dental insurance, $\$ 9$ each on specialist care health insurance and retirement benefits, $\$ 8$ each on vision insurance, prescription coverage, and life insurance. Less than $\$ 5$ each was allocated to personal disability insurance, paid sick time, unemployment insurance, vacation, family leave, mental health care, and supplemental workers' compensation.

\section{Vehicle Ownership}

Finally, because vehicle ownership was the only variable that significantly predicted all three primary outcomes, having health insurance, life insurance, and retirement savings, we examined which drivers were more likely to own their own vehicles. As shown in Table 5, vehicle ownership was associated with several demographic variables. Vehicle owners were more likely than non-vehicle owners to be older $(t=-2.37, p=.018)$, in a higher income bracket $\left(\chi^{2}=13.25\right.$, $p=.004)$, married $\left(\chi^{2}=16.86, p=.001\right)$, South Asian $\left(\chi^{2}=41.57, p=.001\right)$, speak English very well $\left(\chi^{2}=7.11\right.$, $p=.008)$, and have traditional FHV ownership $\left(\chi^{2}=69.77\right.$, $p=.001)$.

\section{Discussion}

Scholars have proposed various frameworks to elucidate the mechanisms by which social and economic factors determine health status and conditions and perpetuate health inequities $[31,32]$. The World Health Organization recognizes that health disparities are the result of poor social, economic, and political policies; the emergence of COVID-19 has further exposed the consequences of these forces on the ability of minority populations and/or those with low socioeconomic status to avoid infection and survive a severe disease [23, 33]. Several U.S. reports have mentioned the difficult and stressful decision faced by drivers of whether to keep working through the pandemic, and risk disease exposure for themselves and their families, communities, and passengers, or whether to pause working and risk potentially losing their means of making a living, namely their vehicle, in addition to income [25, 34]. For those who remained driving, the availability of work declined precipitously [34]. According to a survey of drivers by the New York Taxi Workers Alliance, $82 \%$ reported being at or close to the point of running out of money for food, a sign of acute financial distress [34]. In telephone interviews we conducted from March to June 2020 with 340 NYC drivers who participate in our Taxi Network health promotion program [5], we found evidence of financial and health concerns related to COVID-19, including lack of income (42\%), taxi-related expenses (21\%), food access (17\%), general health concerns (12\%), housing insecurity (10\%), fear of virus exposure (10\%), and stress/ anxiety (7\%). 
Table 4 Understanding of each benefit: no. $(\%) / \mu(\mathrm{SD})$

\begin{tabular}{|c|c|c|c|c|c|c|c|c|c|}
\hline & \multicolumn{3}{|c|}{ Health insurance } & \multicolumn{3}{|l|}{ Life insurance } & \multicolumn{3}{|l|}{ Retirement } \\
\hline & Very well & $\begin{array}{l}\text { Well/not well/not } \\
\text { at all }\end{array}$ & $p$ & Very well & $\begin{array}{l}\text { Well/not well/not } \\
\text { at all }\end{array}$ & $p$ & Very well & $\begin{array}{l}\text { Well/not well/not } \\
\text { at all }\end{array}$ & $p$ \\
\hline Age & $48.80(12.84)$ & 44.03 (11.99) & .002 & $46.00(11.52)$ & $44.63(12.73)$ & .286 & 47.45 (11.87) & $44.13(12.47)$ & .016 \\
\hline $\begin{array}{l}\text { Monthly gross } \\
\text { income }\end{array}$ & & & .240 & & & .508 & & & .421 \\
\hline$\leq \$ 1999$ & $14(5 \%)$ & $29(11 \%)$ & & $17(5 \%)$ & $35(10 \%)$ & & $11(3 \%)$ & $40(12 \%)$ & \\
\hline$\$ 2000-3999$ & $43(16 \%)$ & $107(40 \%)$ & & $52(15 \%)$ & $138(40 \%)$ & & $43(13 \%)$ & $147(43 \%)$ & \\
\hline$\$ 4000-5999$ & $20(7 \%)$ & $31(11 \%)$ & & $20(6 \%)$ & $51(15 \%)$ & & $22(6 \%)$ & $49(14 \%)$ & \\
\hline$\geq \$ 6000$ & $12(4 \%)$ & $14(5 \%)$ & & $12(3 \%)$ & $18(5 \%)$ & & $9(3 \%)$ & $20(6 \%)$ & \\
\hline Financial strain & & & .215 & & & .128 & & & .898 \\
\hline $\begin{array}{l}\text { Difficult to cover } \\
\text { expenses }\end{array}$ & $51(16 \%)$ & $121(38 \%)$ & & $71(18 \%)$ & $146(36 \%)$ & & $56(14 \%)$ & $162(40 \%)$ & \\
\hline $\begin{array}{l}\text { Just enough to } \\
\text { cover expenses }\end{array}$ & $37(12 \%)$ & $68(22 \%)$ & & $31(8 \%)$ & $101(25 \%)$ & & $32(8 \%)$ & $100(25 \%)$ & \\
\hline $\begin{array}{l}\text { Can cover } \\
\text { expenses with } \\
\text { leftover }\end{array}$ & $17(5 \%)$ & $22(7 \%)$ & & $18(4 \%)$ & $33(8 \%)$ & & $14(3 \%)$ & $37(9 \%)$ & \\
\hline Marital status & & & .971 & & & .647 & & & .283 \\
\hline Married & $81(25 \%)$ & $167(52 \%)$ & & $85(21 \%)$ & $215(52 \%)$ & & $80(19 \%)$ & $222(54 \%)$ & \\
\hline Not married & $24(7 \%)$ & $52(16 \%)$ & & $35(8 \%)$ & $77(19 \%)$ & & $23(6 \%)$ & $88(21 \%)$ & \\
\hline $\begin{array}{l}\text { Years of educa- } \\
\text { tion }\end{array}$ & $12.84(3.67)$ & $13.59(4.23)$ & .108 & $13.43(3.62)$ & $13.36(4.06)$ & .872 & $13.32(3.31)$ & $13.40(4.12)$ & .838 \\
\hline Years in the U.S. & $22.95(11.75)$ & $19.28(10.83)$ & .009 & $21.70(10.96)$ & $19.31(10.94)$ & .049 & $22.18(11.35)$ & $19.19(10.77)$ & .022 \\
\hline Birth Region & & & .346 & & & .155 & & & .285 \\
\hline $\begin{array}{l}\text { Sub-Saharan } \\
\text { Africa }\end{array}$ & $18(6 \%)$ & $33(10 \%)$ & & $26(6 \%)$ & $55(13 \%)$ & & $26(6 \%)$ & $53(13 \%)$ & \\
\hline $\begin{array}{c}\text { East Asia/Tibet/ } \\
\text { Southeast Asia }\end{array}$ & $4(1 \%)$ & $12(4 \%)$ & & $5(1 \%)$ & $14(3 \%)$ & & $3(1 \%)$ & $16(4 \%)$ & \\
\hline Latin America & $22(7 \%)$ & $45(14 \%)$ & & $17(4 \%)$ & $66(16 \%)$ & & $17(4 \%)$ & $67(16 \%)$ & \\
\hline $\begin{array}{l}\text { North Africa/ } \\
\text { Middle East/ } \\
\text { Central Asia }\end{array}$ & $7(2 \%)$ & $25(8 \%)$ & & $15(4 \%)$ & $28(7 \%)$ & & $9(2 \%)$ & $34(8 \%)$ & \\
\hline South Asia & $39(12 \%)$ & $86(26 \%)$ & & $40(10 \%)$ & $104(25 \%)$ & & $35(8 \%)$ & $111(27 \%)$ & \\
\hline Other & $16(5 \%)$ & $18(6 \%)$ & & $18(4 \%)$ & $24(6 \%)$ & & $14(3 \%)$ & $28(7 \%)$ & \\
\hline $\begin{array}{l}\text { English profi- } \\
\text { ciency }\end{array}$ & & & .002 & & & .008 & & & .001 \\
\hline Very well & $43(13 \%)$ & $52(16 \%)$ & & $45(11 \%)$ & $70(17 \%)$ & & $43(10 \%)$ & $71(17 \%)$ & \\
\hline $\begin{array}{l}\text { Well/not well/not } \\
\text { at all }\end{array}$ & $62(19 \%)$ & $166(51 \%)$ & & $75(18 \%)$ & $221(54 \%)$ & & $59(14 \%)$ & $238(58 \%)$ & \\
\hline Work shift & & & .073 & & & .127 & & & .108 \\
\hline Day & $64(20 \%)$ & $130(40 \%)$ & & $77(19 \%)$ & $160(39 \%)$ & & $68(16 \%)$ & $168(41 \%)$ & \\
\hline Night & $22(7 \%)$ & $29(9 \%)$ & & $20(5 \%)$ & $49(12 \%)$ & & $16(4 \%)$ & $52(13 \%)$ & \\
\hline Varies & $19(6 \%)$ & $60(19 \%)$ & & $23(6 \%)$ & $83(20 \%)$ & & $20(5 \%)$ & $89(22 \%)$ & \\
\hline Vehicle type & & & .794 & & & .152 & & & .147 \\
\hline App-based FHV & $23(7 \%)$ & $58(18 \%)$ & & $33(8 \%)$ & $73(18 \%)$ & & $21(5 \%)$ & $82(20 \%)$ & \\
\hline Green cab & $22(7 \%)$ & $39(12 \%)$ & & $17(4 \%)$ & $57(14 \%)$ & & $14(3 \%)$ & $61(15 \%)$ & \\
\hline $\begin{array}{l}\text { Medallion yel- } \\
\text { low cab }\end{array}$ & $31(10 \%)$ & $62(19 \%)$ & & $44(11 \%)$ & $79(19 \%)$ & & $34(8 \%)$ & $89(21 \%)$ & \\
\hline Traditional FHV & $30(9 \%)$ & $60(18 \%)$ & & $27(7 \%)$ & $83(20 \%)$ & & $35(8 \%)$ & $78(19 \%)$ & \\
\hline Vehicle ownership & & & .965 & & & .369 & & & .999 \\
\hline Own & $56(18 \%)$ & $119(37 \%)$ & & $56(14 \%)$ & $152(38 \%)$ & & $53(13 \%)$ & $158(39 \%)$ & \\
\hline Don't own & $47(15 \%)$ & $96(30 \%)$ & & $62(15 \%)$ & $135(33 \%)$ & & $49(12 \%)$ & $147(36 \%)$ & \\
\hline
\end{tabular}


Table 4 (continued)

$\mu(\mathrm{SD})$ : mean and standard deviation for continuous variables

Table 5 Vehicle ownership: no. $(\%) / \mu(\mathrm{SD})$

\begin{tabular}{|c|c|c|c|c|c|}
\hline & Owner $(n=214)$ & Not owner $(n=200)$ & $t$ & $\chi^{2}$ & $p$ \\
\hline Age & $46.31(12.26)$ & $43.44(12.38)$ & -2.37 & & 0.018 \\
\hline Monthly gross income & & & & 13.25 & 0.004 \\
\hline$\leq \$ 1999$ & $18(11)$ & $34(5)$ & & & \\
\hline$\$ 2000-3999$ & $96(40)$ & $91(16)$ & & & \\
\hline$\$ 4000-5999$ & $42(11)$ & $29(7)$ & & & \\
\hline$\geq \$ 6000$ & $22(5)$ & $8(4)$ & & & \\
\hline Financial strain & & & & 2.34 & 0.311 \\
\hline Difficult to cover expenses & $106(38)$ & $114(16)$ & & & \\
\hline Just enough to cover expenses & $71(22)$ & $61(12)$ & & & \\
\hline Can cover expenses with left over & $30(7)$ & $21(5)$ & & & \\
\hline Marital status & & & & 16.86 & 0.001 \\
\hline Married & $175(52)$ & $126(25)$ & & & \\
\hline Not married & $39(16)$ & $73(7)$ & & & \\
\hline Years of education & $13.11(3.91)$ & $13.62(4.03)$ & 1.27 & & 0.203 \\
\hline Years in the U.S. & $20.40(11.09)$ & $19.60(10.92)$ & -0.72 & & 0.469 \\
\hline Birth Region & & & & 41.57 & 0.001 \\
\hline Sub-Saharan Africa & $18(10)$ & $62(6)$ & & & \\
\hline East Asia/Tibet/Southeast Asia & $15(4)$ & $4(1)$ & & & \\
\hline Latin America & $53(14)$ & $28(7)$ & & & \\
\hline North Africa/Middle East/Central Asia & $25(8)$ & $19(2)$ & & & \\
\hline South Asia & $83(26)$ & $64(12)$ & & & \\
\hline Other & $19(6)$ & $23(5)$ & & & \\
\hline English proficiency & & & & 7.11 & 0.008 \\
\hline Very well & $46(16)$ & $67(13)$ & & & \\
\hline Well/not well/not at all & $167(51)$ & $131(19)$ & & & \\
\hline Work shift & & & & 2.44 & 0.296 \\
\hline Day & $121(40)$ & $116(20)$ & & & \\
\hline Night & $30(9)$ & $36(7)$ & & & \\
\hline Varies & $63(19)$ & $47(6)$ & & & \\
\hline Vehicle type & & & & 69.77 & 0.001 \\
\hline App-based FHV & $63(18)$ & $44(7)$ & & & \\
\hline Green cab & 49 (12) & $22(7)$ & & & \\
\hline Medallion yellow cab & $25(19)$ & $97(10)$ & & & \\
\hline Traditional FHV & 77 (18) & $37(9)$ & & & \\
\hline
\end{tabular}

$\mu(\mathrm{SD})$ : mean and standard deviation for continuous variables

$\chi^{2}$ : chi square (categorical variables)

$t: t$ test (continuous variables)
The predominantly immigrant taxi and FHV driving population has long faced health inequities driven by complex interactions of occupation, immigration status, and ethnicity/ race. Furthermore, the advent and popularity of ride-sharing apps has disrupted the taxi industry [35], and NYC drivers have faced immense new competition, forcing the value of yellow taxi medallions to drop from $\$ 1.3$ million in 2013 to $\$ 160,000-\$ 250,000$ in 2018 , leaving many drivers with debt exceeding their medallion's value and/or draining the value of an asset that had provided a financial cushion and possible source of retirement funding [10]. Despite the occupation's exponential growth and drivers' financial challenges, limited research has investigated their financial and physical and mental health benefits access.

The Bureau of Labor Statistics estimates the average wage of taxi/FHV drivers to be $\$ 25,980 /$ year [36], which 
is below the national poverty threshold for a family of four and below the NYC threshold for a family of three [37, 38]. This suggests that taxi/FHV drivers may be at financial risk, particularly as they lack traditional employer-sponsored benefits, such as health insurance and paid sick time. Few locales have implemented legislation to improve the financial, physical, and emotional health of taxi/FHV drivers.

Many more taxi/FHV drivers in the current study had health insurance than in prior studies conducted before adoption of the Affordable Care Act ( $80 \%$ vs. 46\%) [39]. Nevertheless, the uninsured rate in this study is nearly double NYC's $10.9 \%$ in 2017 [40]. Only a small percentage of drivers had life insurance and retirement savings compared to the general population ( $20 \%$ vs. $60 \%$ and $25 \%$ vs $58 \%$, respectively) [41, 42]. Further, a 2011 National Bureau of Economic Research working paper found that financial literacy among older Americans is generally low, particularly among ethnic/racial minorities [43], meaning that taxi drivers could be at particular risk. This highlights opportunities to increase this population's access to health and financial resources with financial literacy education.

South Asian region of birth was associated with health insurance, retirement savings, and vehicle ownership likelihood. Vehicle ownership was associated with health insurance, life insurance, and retirement savings. A greater number of years in the U.S. also predicted life insurance coverage. Traditionally, a large proportion of NYC taxi drivers were from South Asian countries and may benefit from experience and a large and well-established network of family and community members who can explain the importance of financial/health benefits and how to use them. However, sub-Saharan African drivers are a rapidly growing group [44], and culturally tailored education programs for these and other newer arrivals could help narrow the benefits gap.

Drivers able to cover their household expenses with some left over and drivers with more years of education were more likely to have life insurance and retirement savings. Drivers who can accommodate their financial responsibilities are more likely to have the means to direct resources towards financial planning opportunities than financially strained drivers. Although we advocate for the importance of these benefits, steps are needed to make them feasible for many drivers.

Although vehicle type was associated with having life insurance and retirement savings, many yellow taxi drivers no longer have a valuable asset in their medallions, and competition has increased for all drivers [8-10]. Our research suggests green cab drivers as a target for intervention, but policy makers should be aware that industry changes may also have put other drivers in this category.

Less than $40 \%$ of drivers indicated understanding any of the insurance and benefits presented to them. Rates of understanding of health insurance were low even among drivers with health insurance, and a small number did not know what theirs covered. There is a need for benefits education among drivers, so that possessing the benefits translates into using them.

These findings on health and financial benefits among this population are timely. Despite the recent driver suicides and documented stressful working conditions and financial strain experienced by drivers, many in our study were not aware of and did not value mental health coverage as highly as other types of health coverage. Financial strain is strongly associated with depression and lowered self-esteem among immigrant populations [45] and is consistently associated with poor health among African Americans [46]. Job instability and financial strain have predicted increased inflammation (C-reactive protein) in Mexican immigrants, e.g. [47]. Furthermore, mental health issues may be particularly stigmatized in immigrant communities [48]. In the predominantly immigrant and minority NYC taxi driver population, awareness and promotion of mental health benefits should be prioritized.

Financial strain poses physical health risks that can particularly affect men. Longitudinal changes in financial strain have been associated with changes in ambulatory systolic blood pressure; however, improvements in chronic financial strain may result in improved cardiovascular and neuroendocrine functioning among men [49]. Among African American men, financial strain has been associated with shorter leukocyte telomere length, an indicator of cellular aging [50]. Drivers may also find gender rolebased expectations to be a source of financial stress; NYC South Asian taxi drivers have reported stressors around fulfilling familial obligations to be the sole or main providers [1]. Therefore, it is possible that the mostly male taxi/ FHV-driving population may experience financial strain compounded with social pressures that could ultimately affect their physical health.

While prior initiatives have sought to understand and provide interventions around taxi and FHV drivers' health concerns in NYC [4, 39] and other U.S. cities [51-53], this study represents the first systematic examination of drivers' potential financial determinants of health in unison with their health insurance coverage. This study reveals compelling addressable gaps in health insurance coverage, the understanding of work-related benefits, and financial literacy among NYC's large taxi/FHV-driving population. Drivers have a strong interest in obtaining the insurance and benefits that they do not currently have. A series of education, navigation, and advising services and programs, combined with necessary policy changes to make these programs accessible to drivers are indicated. 


\section{Intervention and Policy Recommendations}

Taxi/FHV drivers are difficult to reach from a public health perspective $[1,4,51]$. However, their occupational infrastructure has a series of assets to facilitate health and financial literacy interventions. For example, in our team's prior work, we have found that drivers are linked by cell phones and driver-managed app groups, embedded in community- and faith-based organizations, and accessible through occupational structures (e.g., garage and base networks, airport holding lots, driver schools, taxi inspection station, and Taxi and Limousine Commission information dissemination channels). Second, the mandated taxi physical exam in NYC is a rare and critical opportunity to provide drivers with linkages to insurance and benefits navigation. Third, license renewals and vehicle inspections provide intervention opportunities.

Legislative and/or policy changes that back free multilingual health and financial literacy programs, materials, and navigation developed with input from the driver community are necessary. This programming should take advantage of existing consumer resources, such as NYC's Office of Citywide Health Insurance Access materials and the multilingual Immigrant Health and Cancer Disparities Service Health Access Facilitator Program (a navigation program), which enrolls community members in health insurance coverage, and provides education on primary care, preventive medicine, and preparing for a health care visit. During the COVID-19 crisis, this program addressed drivers' financial and health concerns by navigating them to available resources, including food, finance, housing, bill payment assistance, and mental and general health resources, as needed. However, ongoing efforts and outreach are imperative to supporting drivers through this acute emergency and beyond.

Educational efforts should focus not only on program enrolment but also on protection from potential financial pitfalls. In 2018, NYC Council presented a package of bills to prevent a recurrence of the predatory practices that had led to the overvaluing of taxi medallions, including initiatives for eliminating fees for medallion owners and financial counselling for new drivers [54]. Steps such as these are timely and necessary.

Affordable benefits are key. An affordable package of benefits should be developed and disseminated through the available channels. Enacting a mandated benefits enrolment program for taxi drivers would improve overall rates of health and financial protection in emergent situations and limit the impact of any financial ramifications.

\section{Study Limitations}

Time and resource constraints precluded random sampling, so a stratified sampling methodology captured subgroups of drivers proportionate to subgroups in the NYC driving population. Despite a large sample size, sampling locations and times potentially skewed the results. In this cross-sectional study, we were unable to determine causal relationships between variables. Finally, the data were self-reported, so subject to bias or misunderstanding of questions, and financial strain was assessed with one item rather than a comprehensive measure of drivers' finances. Future work should address these limitations.

\section{Conclusion}

Drivers reported benefits information and utilization gaps, coupled with a desire to receive better coverage, indicating a need for health and other insurance, financial planning services, and benefits that are traditionally associated with the workplace. Community assets can facilitate the planning and dissemination of information and resources to improve the medical and financial health of taxi and FHV drivers. Policy and legislative changes are fundamental to serving this large and growing at-risk population, which has been hit especially hard by COVID-19 and is in more need than ever before.

Acknowledgements We thank Members of the Immigrant Health and Cancer Disparities (IHCD) Taxi Network and the South Asian Council for Social Services (SACSS) for their insight and expertise.

Author Contributions FG, SM, BN, JR, NR, and JL conceived/ designed the work; acquired, analyzed, and interpreted the data; and drafted and revised the work for critical intellectual content. SYK contributed to data analysis, visualization, interpretation, and manuscript drafting. AO contributed to study design, data management and analysis, and critically revising the manuscript. AA contributed to data collection and drafting and critically revising the manuscript. All authors approved the final version and agree to be accountable for all aspects of the work, ensuring that questions related to the accuracy or integrity of any part of the work have been appropriately investigated and resolved.

Funding Grant sponsor: National Institute on Minority Health and Health Disparities; Grant Number: U01 MD010648; Grant sponsor: National Institute of Nursing Research; Grant Number: R01 NR015265; Grant sponsor: National Cancer Institute; Grant Number: P30 CA008748.

\section{Compliance with Ethical Standards}

Conflict of interest To the best of our knowledge, no conflict of interest, financial or other, exists for any of the authors 
Editorial Approval The authors thank Sonya J. Smyk, Memorial Sloan Kettering Cancer Center, for editorial support. She was not compensated beyond her regular salary.

Informed Consent This study was approved as exempt research by the Institutional Review Board at Memorial Sloan Kettering Cancer Center.

\section{References}

1. Gany, F., Gill, P., Ahmed, A., Acharya, S., \& Leng, J. (2013). "Every disease....man can get can start in this cab": Focus groups to identify south Asian taxi drivers' knowledge, attitudes and beliefs about cardiovascular disease and its risks. Journal of Immigrant and Minority Health, 15(5), 986-992. https://doi. org/10.1007/s10903-012-9682-7.

2. Murray, K. E., Buul, A., Aden, R., et al. (2019). Occupational health risks and intervention strategies for US taxi drivers. Health Promotion International, 34(2), 323-332. https://doi.org/10.1093/ heapro/dax082.

3. Elshatarat, R. A., \& Burgel, B. J. (2016). Cardiovascular risk factors of taxi drivers. Journal of Urban Health: Bulletin of the New York Academy of Medicine, 93(3), 589-606. https://doi. org/10.1007/s11524-016-0045-x.

4. Gany, F., Bari, S., Gill, P., Loeb, R., \& Leng, J. (2015). Step on it! Impact of a workplace New York City taxi driver health intervention to increase necessary health care access. American Journal of Public Health, 105(4), 786-792. https://doi.org/10.2105/ ajph.2014.302122.

5. Mirpuri, S., Ocampo, A., Narang, B., Roberts, N., \& Gany, F. (2018). Discrimination as a social determinant of stress and health among New York City taxi drivers. Journal of Health Psychology. https://doi.org/10.1177/1359105318755543.

6. Bureau of Labor Statistics. (2016). Taxi drivers and chauffeurs: Occupational outlook handbook, 2016-17 Edition. Retrieved August 19, 2019, from http://www.bls.gov/ooh/transportationand-material-moving/taxi-drivers-and-chauffeurs.htm.

7. Bureau of Labor Statistics. (2019). Labor force statistics from the current population survey. US Government, Washington, DC. Retrieved August 12, 2020, from https://www.bls.gov/cps/cpsaa t18.htm.

8. NYC Taxi \& Limousine Commission (TLC). (2018). Factbook 2018. Retrieved June 19, 2019, from https://www1.nyc.gov/site/ tlc/about/fact-book.page.

9. Rosenthal, B. M. (2019). "They were conned": How reckless loans devastated a generation of taxi drivers. The New York Times. Retrieved January 5, 2020, from https://www.nytim es.com/2019/05/19/nyregion/nyc-taxis-medallions-suicides.html.

10. Walker, A. (2018). In NYC, 139 prized yellow taxi medallions will hit the auction block. Curbed New York.

11. PFM Group Consulting, Schaller Consulting. (2018). PFM/ Schaller Taxi Industry report: Evaluation and recommendations to improve the health of the Taxi Industry in San Francisco.

12. Parrott, J. A., \& Reich, M. (2018). An earnings standard for New York City's app-based drivers: Economic analysis and policy assessment. Retrieved June 19, 2019, from http://www.centernyc. org/an-earnings-standard.

13. Kahn, J. R., \& Pearlin, L. I. (2006). Financial strain over the life course and health among older adults. Journal of Health and Social Behavior, 47(1), 17-31. https://doi.org/10.1177/00221 4650604700102

14. Sturgeon, J. A., Arewasikporn, A., Okun, M. A., Davis, M. C., Ong, A. D., \& Zautra, A. J. (2016). The psychosocial context of financial stress: Implications for inflammation and psychological health. Psychosomatic Medicine, 78(2), 134-143. https://doi. org/10.1097/psy.0000000000000276.

15. Fitzsimmons, E. G. (2018). Why are taxi drivers in New York killing themselves? The New York Times. Retrieved August 19, 2019, from https://www.nytimes.com/2018/12/02/nyregion/taxidrivers-suicide-nyc.html.

16. Mirpuri, S., Gill, P., Ocampo, A., et al. (2018). Discrimination and health among taxi drivers in New York and Toronto. Journal of Community Health, 43(4), 667-672. https://doi.org/10.1007/ s10900-018-0466-4.

17. Lim, S. M., \& Chia, S. E. (2015). The prevalence of fatigue and associated health and safety risk factors among taxi drivers in Singapore. Singapore Medical Journal, 56(2), 92-97. https://doi. org/10.11622/smedj.2014169.

18. Nakano, Y., Nakamura, S., Hirata, M., et al. (1998). Immune function and lifestyle of taxi drivers in Japan. Industrial Health, 36(1), 32-39. https://doi.org/10.2486/indhealth.36.32.

19. Chen, J. C., Dennerlein, J. T., Shih, T. S., et al. (2004). Knee pain and driving duration: A secondary analysis of the Taxi Drivers' Health Study. American Journal of Public Health, 94(4), 575581. https://doi.org/10.2105/ajph.94.4.575.

20. Chen, J. C., Chen, Y. J., Chang, W. P., \& Christiani, D. C. (2005). Long driving time is associated with haematological markers of increased cardiovascular risk in taxi drivers. Occupational and Environmental Medicine, 62(12), 890-894. https://doi. org/10.1136/oem.2005.020354.

21. Kurosaka, K., Daida, H., Muto, T., Watanabe, Y., Kawai, S., \& Yamaguchi, H. (2000). Characteristics of coronary heart disease in Japanese taxi drivers as determined by coronary angiographic analyses. Industrial Health, 38(1), 15-23. https://doi.org/10.2486/ indhealth.38.15.

22. Hansen, J., Raaschou-Nielsen, O., \& Olsen, J. H. (1998). Increased risk of lung cancer among different types of professional drivers in Denmark. Occupational and Environmental Medicine, 55(2), 115-118. https://doi.org/10.1136/oem.55.2.115.

23. Heymann, J., Raub, A., Waisath, W., et al. (2020). Protecting health during COVID-19 and beyond: A global examination of paid sick leave design in 193 countries. Global Public Health, 15(7), 925-934. https://doi.org/10.1080/17441692.2020.1764076.

24. Ghilarducci, T., \& Farmand, A. (2020). Older workers on the COVID-19-frontlines without paid sick leave. Journal of Aging \& Social Policy. https://doi.org/10.1080/08959420.2020.1765685.

25. Long, H. (2020). A New York City taxi driver kept working to pay bills. Now he and his family are sick. Washington Post. 2020 April 4. Retrieved May 10, 2020, from https://www.washington post.com/business/2020/04/04/taxi-driver-covid/.

26. Killerby, M., Link-Gelles, R., Haight, S., et al. (2020). Characteristics associated with hospitalization among patients with COVID-19-Metropolitan Atlanta, Georgia, March-April 2020. MMWR Weekly Report. http://dx.doi.org/10.15585/mmwr.mm692 $5 \mathrm{e} 1$.

27. Klaes, M., \& Sent, E.-M. (2005). A conceptual history of the emergence of bounded rationality. History of Political Economy, 37(1), 27-59.

28. Simon, H. A. (1955). A behavioral model of rational choice. The Quarterly Journal of Economics, 69(1), 99-118.

29. Kahneman, D., \& Tversky, A. (1979). Prospect theory: An analysis of decision under risk. Econometrica, 47(2), 363-391.

30. NYC Taxi \& Limousine Commission (TLC). (2016). 2016 Factbook. Retrieved June 19, 2019, from https://www1.nyc.gov/ assets/tlc/downloads/pdf/2016_tlc_factbook.pdf.

31. Krieger, N. (1994). Epidemiology and the web of causation: Has anyone seen the spider? Social Science and Medicine, 39(7), 887-903.

32. HealthyPeople.gov. Social Determinants of Health. (2020). Retrieved August 10, 2020, from https://www.healthypeo 
ple.gov/2020/topics-objectives/topic/social-determinants-of-healt h.

33. Commission on Social Determinants of Health. (2008). Closing the gap in a generation: Health equity through action on the social determinants of health. Geneva: World Health Organization.

34. Chan, M. (2020). New York City's taxi drivers are in peril as they brave the coronavirus and uncertain future. Time, 15, 2020. Retrieved June 10, 2020, from https://time.com/5836223/ nyc-taxi-drivers-coronavirus/..

35. Wallsten, S. (2015). The competitive effects of the sharing economy: How is Uber changing taxis?. Washington: Technology Policy Institute.

36. US Bureau of Labor Statistics. (2019). Taxi drivers, ride-hailing drivers, and chauffeurs. In Occupational outlook handbook. US Government, Washington, DC. Retrieved July 8, 2020, from https ://www.bls.gov/ooh/transportation-and-material-moving/taxidrivers-and-chauffeurs.htm.

37. U.S. Department of Health \& Human Services. (2020). U.S. Federal Poverty Guidelines used to determine financial eligibility for certain federal programs. In Poverty guidelines. US Government, Washington, DC. Retrieved July 8, 2020, from https://aspe.hhs. gov/poverty-guidelines.

38. Mayor's Office for Economic Opportunity. (2018). 2018 poverty report. New York: NYC.gov, Mayor's Office for Economic Opportunity TCoNY.

39. Gany, F., Bari, S., Gill, P., et al. (2016). Step on it! Workplace cardiovascular risk assessment of New York City yellow taxi drivers. Journal of Immigrant and Minority Health, 18(1), 118-134. https ://doi.org/10.1007/s10903-015-0170-8.

40. NYC.gov. (2017). De Blasio administration releases Mayor's management report for fiscal year 2017. Retrieved August 19, 2019, from https://www1.nyc.gov/office-of-the-mayor/news/593-17/deblasio-administration-releases-mayor-s-management-report-fisca 1-year-2017.

41. Insurance Information Institute. (2020). Facts + Statistics: Life insurance. Retrieved August 11, 2020, from https://www.iii.org/ fact-statistic/facts-statistics-life-insurance.

42. Garon, T., Dunn, A., Golvala, K., Wilson, E. (2018). U.S. financial health pulse: 2018 baseline survey results. Center for Financial Services Innovation.

43. Lusardi, A., \& Mitchell, O. S. (2011). Financial literacy and planning: Implications for retirement wellbeing. National Bureau of Economic Research.

44. Echeverria-Estrada, C., \& Batalova, J. (2019) Migration Policy Institute. Sub-Saharan African Immigrants in the United States. Retrieved February 20, 2020, from https://www.migrationpolicy .org/article/sub-saharan-african-immigrants-united-states.
45. Angel, R. J., Frisco, M., Angel, J. L., \& Chiriboga, D. A. (2003). Financial strain and health among elderly Mexican-origin individuals. Journal of Health and Social Behavior, 44(4), 536-551.

46. Szanton, S. L., Thorpe, R. J., \& Whitfield, K. (2010). Life-course financial strain and health in African-Americans. Social Science and Medicine, 71(2), 259-265. https://doi.org/10.1016/j.socsc imed.2010.04.001.

47. Steffen, P. R., Walker, J., Meredith, R., \& Anderson, C. (2016). The effects of job instability and financial strain on C-reactive protein in a sample of Mexican immigrants. Ethnicity and Disease, 26(1), 37-44. https://doi.org/10.18865/ed.26.1.37.

48. Saechao, F., Sharrock, S., Reicherter, D., et al. (2012). Stressors and barriers to using mental health services among diverse groups of first-generation immigrants to the United States. Community Mental Health Journal, 48(1), 98-106. https://doi.org/10.1007/ s10597-011-9419-4.

49. Steptoe, A., Brydon, L., \& Kunz-Ebrecht, S. (2005). Changes in financial strain over three years, ambulatory blood pressure, and cortisol responses to awakening. Psychosomatic Medicine, 67(2), 281-287. https://doi.org/10.1097/01.psy.0000156932.96261.d2.

50. Schrock, J. M., Adler, N. E., Epel, E. S., et al. (2018). Socioeconomic status, financial strain, and leukocyte telomere length in a sample of African American midlife men. Journal of Racial and Ethnic Health Disparities, 5(3), 459-467. https://doi.org/10.1007/ s40615-017-0388-3.

51. Apantaku-Onayemi, F., Baldyga, W., Amuwo, S., et al. (2012). Driving to better health: Cancer and cardiovascular risk assessment among taxi cab operators in Chicago. Journal of Health Care for the Poor and Underserved, 23(2), 768-780. https://doi. org/10.1353/hpu.2012.0066.

52. Blasi, G., \& Leavitt, J. (2006). Driving poor: Taxi drivers and the regulation of the taxi industry in Los Angeles. Los Angeles: UCLA Institute of Industrial Relations.

53. Burgel, B. J., Gillen, M., \& White, M. C. (2012). Health and safety strategies of urban taxi drivers. Journal of Urban Health: Bulletin of the New York Academy of Medicine, 89(4), 717-722. https:// doi.org/10.1007/s11524-012-9685-7.

54. Rosenthal, B. M. (2019). As thousands of taxi drivers were trapped in loans, top officials counted the money. The New York Times. Retrieved August 19, 2019, from https://www.nytim es.com/2019/05/19/nyregion/taxi-medallions.html.

Publisher's Note Springer Nature remains neutral with regard to jurisdictional claims in published maps and institutional affiliations. 